\title{
The Role of Caspase-3, Apoptosis-Inducing Factor, and B-cell Lymphoma-2 Expressions in Term Premature Rupture of Membrane
}

\author{
Ketut Surya Negara ${ }^{1}$ Ketut Suwiyoga ${ }^{1}$ Tjokorda Gede Astawa Pemayun ${ }^{1}$ Anak Agung Raka Sudewi ${ }^{2}$ \\ Nyoman Mantik Astawa ${ }^{3}$ I Gusti Nyoman Kamasan Arijana ${ }^{4}$ Ketut Tunas ${ }^{5}$ \\ ${ }^{1}$ Department of Obstetrics and Gynecology, Medical Faculty of \\ Udayana University /Sanglah Hospital, Bali, Indonesia \\ 2 Department of Neurology, Medical Faculty of Udayana University/ \\ Sanglah Hospital, Bali, Indonesia

\begin{abstract}
Address for correspondence Ketut Surya Negara, O\&G specialist, MFM Consultant, Department of Obstetrics and Gynecology, Sanglah General Hospital, Diponegoro street 80113, Denpasar, Bali, Indonesia (e-mail: tutsuryanegara@gmail.com).
\end{abstract}

${ }^{3}$ Laboratory of Veterinary Medicine, Udayana University, Bali, Indonesia

${ }^{4}$ Biomedic Laboratory of Medical Faculty, Udayana University, Bali, Indonesia

${ }^{5}$ Department of Public Health, Dhyana Pura University, Bali, Indonesia

Rev Bras Ginecol Obstet 2018;40:733-739.

\begin{abstract}
Keywords

- PROM

- caspase-3

- apoptosis inducing factor

- B-cell lymphoma-2 expression

- apoptosis

Objective To determine the role of caspase-3, apoptosis-inducing factor (AIF), and Bcell lymphoma-2 (Bcl-2) expressions in term premature rupture of membrane (PROM). Methods An analytic observational study with case-control design was conducted, involving 52 subjects (37-42 weeks of gestation) who were divided into 2 groups: 26 cases of term delivery with PROM, and 26 controls of term delivery without PROM. The expressions of caspase- 3 , AIF, and Bcl-2 in the amniotic membrane were determined by immunohistochemistry. Data were analyzed using the chi-squared test. The risk of PROM was expressed by odds ratio (OR).

Results There were no significant differences in age, parity and body mass index between the two groups $(p>0.05)$. High caspase- 3 and AIF expressions increased the risk of PROM 17.64 times $(\mathrm{OR}=17.64 ; 95 \% \mathrm{Cl}=4.44-70.07 ; p=0.001)$ and 9.45 times $(\mathrm{OR}=9.45 ; 95 \% \mathrm{Cl}=2.62-34.07 ; p=0.001)$, respectively, while low $\mathrm{Bcl}-2$ expression increased 10.39 times $(\mathrm{OR}=10.39 ; 95 \% \mathrm{Cl}=2.73-39.56 ; p=0.001)$ the risk of PROM .

Conclusion High caspase-3 and AlF expressions and low Bcl-2 expression were risk factors for term PROM. Caspase-dependent and independent pathways of apoptosis were involved in the mechanism of PROM in term pregnancy.
\end{abstract}

\section{Introduction}

Premature rupture of the membrane (PROM) is one of the complications of pregnancy, and it is associated with maternal and neonatal morbidities. ${ }^{1}$ Term PROM is defined as the rupture of the fetal membrane prior to the onset of labor in a term pregnancy. The etiology of PROM is multi-factorial, and its pathobiological mechanisms are unclear. ${ }^{2}$ One of the factors involved in the endogenous and exogenous mecha- nisms associated with the increased risk of PROM is the occurrence of programmed cell death, or apoptosis.

The incidence of PROM worldwide varies between 5 and $10 \%$, and almost $80 \%$ of the cases occur at term pregnancy. ${ }^{1,2}$ In China, the reported incidence of PROM is higher, around $19.53 \%$ of all pregnancies. ${ }^{3}$ Budijaya et al $(2017)^{4}$ reported 212 cases of PROM in 1,450 deliveries (14.62\%) at the Sanglah Hospital Denpasar, Bali, Indonesia; 179 cases $(84.43 \%)$ were term received

June 20, 2018

accepted

September 18, 2018
DOI https://doi.org/

10.1055/s-0038-1675611. ISSN 0100-7203.
Copyright $\odot 2018$ by Thieme Revinter Publicações Ltda, Rio de Janeiro, Brazil
License terms

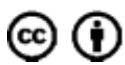


pregnancies ( $\geq 37$ weeks), while 33 cases $(15.57 \%)$ were preterm pregnancies.

Premature rupture of the membrane is associated with various complications for both the mother and the newborns. Maternal complications such as chorioamnionitis are found in $9 \%$ of the pregnancies with PROM, and the incidence is greater in preterm pregnancy, reported in between 13 and $60 \%$ of these cases. ${ }^{5,6}$ Placental abruption occurs in between 4 and $12 \%$ of the pregnancies with PROM. Neonatal complications of PROM, such as intrauterine infection, umbilical cord compression, respiratory distress syndrome (RDS), necrotizing enterocolitis, intraventricular hemorrhage, and sepsis are more common in preterm labor. Overall, PROM is associated with $21.4 \%$ perinatal morbidity and with a mortality rate of between 18 and $20 \%{ }^{7-9}$

The cause of PROM is multifactorial, and its mechanism is unclear. The weakening of the extracellular matrix in the fetal membrane due to collagen degradation predisposes pregnant women to PROM. ${ }^{5}$ This process is thought to be the result of biochemical remodeling and apoptosis, as well as of membrane stretching, which lead directly to tissue damage. ${ }^{10-12}$

Apoptosis plays an integral role in the pathogenesis of PROM. Apoptotic cells are found in the amniotic and chorionic layers and are most abundant at the site of the rupture, known as the paracervical weak zone. ${ }^{13-15}$ The process involved in the formation of the paracervical weak zone, in addition to the remodeling process, is closely related to the apoptotic mechanism. Apoptotic cells were found to be more abundant in the amniotic membrane of patients with PROM compared with patients without PROM, while the rate of apoptosis was found to be highest in the vicinity of the cervix compared with the fundal area. ${ }^{16-18}$

Apoptosis occurs through two mechanisms: caspase-dependent and caspase-independent pathways. The caspasedependent pathway can be triggered intrinsically by mitochondrial metabolic failure or extrinsically by death receptor activation. The caspase-independent pathway can be triggered by mitochondrial proteins such as apoptosis-inducing factor (AIF) and endonuclease $\mathrm{G}$ (endoG), which are produced by the mitochondrial membrane due to the depolarization of the outer mitochondrial membrane. ${ }^{19-21}$

The activation of caspase is the initial step of apoptosis, with caspase-3 as the most important executor caspase. Caspase-3 plays an important role in the morphologic changes of the cells and in the biochemical events related to the implementation and completion of apoptotic processes. ${ }^{20,22}$ When a cell is exposed to infection or to a stressor, apoptosis may occur without involving the classic caspasedependent pathway. In this state, apoptosis occurs through another mechanism, called caspase-independent pathway, which involves Bax, a member of the B-cell lymphoma-2 (Bcl-2) pro-apoptotic family. Studies have suggested that the role of the Bcl-2 protein family in the caspase-independent apoptotic pathway is by affecting mitochondria, which leads to DNA fragmentation. ${ }^{22-24}$ The fact that excessive expression of Bax or Bak proteins can induce cell death without involving caspase indicates that factors other than caspase may also initiate apoptosis. Some of these factors are present in mitochondria, namely AIF, which causes chromatin con- densation and the release of cytochrome $\mathrm{C}$ in the absence of caspase activation. ${ }^{20,24,25}$

\section{Methods}

This is an analytic observational study with a case-control design involving 52 subjects (37-42 weeks of gestation), who were divided into case and control groups. The study was conducted at the Sanglah Central General Hospital, Bali, Indonesia, and at affiliated educational district hospitals. Cases ( $n=26$ ) were term pregnancies with PROM, and controls $(n=26)$ were term pregnancies without PROM. Premature rupture of the membrane was defined as the spontaneous rupture of the fetal membrane, at least 1 hour before the onset of labor (regular uterine contractions and cervical dilation or effacement). Patients with obesity, maternal infection, systemic illness, obstetrics complications, smoking habit, and history of preterm PROM in the current pregnancy were excluded.

The deliveries of the subjects were spontaneous or medically-induced. After delivery, the placentas were examined, and the site of rupture was visually identified. The study materials were taken from the edge of the ruptured membranes. The expression of caspase-3, AIF, and $\mathrm{Bcl}-2$ was determined using immunohistochemistry examination, performed at the Integrated Biomedical Laboratory of the Medical Faculty of the Udayana University, Bali, Indonesia. The measurement was done in a semiquantitative fashion; positive expression was defined if $\geq 10 \%$ of the cells were stained. The independent $t$-test was used to analyze the differences in caspase-3, AIF, and Bcl-2 expressions between the two groups. The correlation between caspase-3, AIF, and Bcl-2 expression with PROM was assessed using the chi-squared test and is expressed in odds ratio (OR).

\section{Results}

A total of 52 research samples were collected, comprising 26 samples with term labor with PROM, and 26 samples of term labor without PROM. The statistical test using the independent $t$-test showed that there were no significant differences in age, parity, and body mass index (BMI) between the two groups $(p>0.05)$.

In - Table 1, we can see that the mean age of the case group was $27.62 \pm 6.23$ years old, and in the control group it was $29.65 \pm 5.90$ years old $(p=0.231)$. The mean parity of

Table 1 Distribution of age, parity, and BMI in both groups

\begin{tabular}{|l|l|l|l|l|l|}
\hline \multicolumn{1}{|c|}{$\begin{array}{c}\text { Risk } \\
\text { Factor }\end{array}$} & \multicolumn{2}{|c|}{$\begin{array}{c}\text { Case } \\
\text { group } \\
(\boldsymbol{n}=26)\end{array}$} & \multicolumn{2}{c|}{$\begin{array}{c}\text { Control } \\
\text { group } \\
(\boldsymbol{n}=26)\end{array}$} & \multirow{2}{*}{-value } \\
\cline { 2 - 5 } & Mean & SD & Mean & SD & \\
\hline $\begin{array}{l}\text { Age } \\
\text { (years old) }\end{array}$ & 27.62 & 6.23 & 29.65 & 5.90 & 0.231 \\
\hline Parity & 0.69 & 0.84 & 1.19 & 1.06 & 0.065 \\
\hline $\begin{array}{l}\text { BMl } \\
\left(\mathrm{kg} / \mathrm{m}^{2}\right)\end{array}$ & 25.83 & 5.28 & 23.63 & 4.58 & 0.115 \\
\hline
\end{tabular}

Abbreviations: BMI, body mass index; SD, standard deviation. 
The Role of Caspase-3, AIF, and B-cell Lymphoma-2 Expressions Negara et al. 735

Table 2 The expressions of caspase-3, AIF, and $\mathrm{Bcl}-2$ in amniotic epithelial cells at term pregnancy and the risk of PROM

\begin{tabular}{|c|c|c|c|c|c|c|}
\hline & & \multicolumn{2}{|c|}{ Group } & \multirow[t]{2}{*}{ OR } & \multirow[t]{2}{*}{$95 \% \mathrm{Cl}$} & \multirow[t]{2}{*}{$p$-value } \\
\hline & & Case & control & & & \\
\hline \multirow[t]{2}{*}{ Caspase -3} & High & 21 & 5 & \multirow[t]{2}{*}{17.64} & \multirow[t]{2}{*}{$4.44-70.07$} & \multirow[t]{2}{*}{0.001} \\
\hline & Low & 5 & 21 & & & \\
\hline \multirow[t]{2}{*}{ AIF } & High & 21 & 8 & \multirow[t]{2}{*}{9.45} & \multirow[t]{2}{*}{$2.62-34.07$} & \multirow[t]{2}{*}{0.001} \\
\hline & Low & 5 & 18 & & & \\
\hline \multirow[t]{2}{*}{$\mathrm{Bcl}-2$} & Low & 22 & 9 & \multirow[t]{2}{*}{10.39} & \multirow[t]{2}{*}{$2.73-39.56$} & \multirow[t]{2}{*}{0.001} \\
\hline & High & 4 & 17 & & & \\
\hline
\end{tabular}

Abbreviations: AIF: apoptosis inducing factor; Bcl-2, B-cell lymphoma-2; Cl, confidence interval; OR, odds ratio; PROM, premature rupture of membrane.

the case group was $0.69 \pm 0.84$, and in the control group it was $1.19 \pm 1.06(p=0.065)$. The mean BMI of the case group was $25.83 \pm 5.28 \mathrm{~kg} / \mathrm{m} 2$, and in the control group it was $23.63 \pm 4.58 \mathrm{~kg} / \mathrm{m} 2(p=0.115)$. These results showed that there was no significant characteristic difference between the two study groups ( $p>0.05)$.

As we can see in - Table 2, we have found that high expression of caspase- 3 increases 17.64 times the risk of PROM (OR $=17.64 ; 95 \% \mathrm{CI}=4.44-70.07 ; p=0.001)$, and that high AIF expression increased 9.45 times the risk of PROM (OR $=9.45 ; 95 \% \mathrm{CI}=2.62-34.07 ; p=0.001)$. The immunohistochemical examination images of caspase-3 and AIF expression are presented in -Figs. 1 and 2. We have also found that low expression of $\mathrm{Bcl}-2$ increased 10.39 times the risk of PROM (OR $=10.39 ; 95 \% \mathrm{CI}=2.73-39.56$; $p=0.001)$. The immunohistochemical examination image of $\mathrm{Bcl}-2$ expression is presented in - Fig. 3 .

\section{Discussion}

Budijaya et al $(2017)^{4}$ found that the incidence of PROM in term pregnancies ( $\geq 37$ weeks) was higher than in preterm pregnancies ( $<37$ weeks): 179 cases $(84.43 \%$ ) and 33 cases (15.57\%), respectively. Similarly, Adeniji et al $(2013)^{1}$ reported that most of the cases of PROM (64\%) occurred in term pregnancy, while $35.1 \%$ of the cases occurred in preterm pregnancy. Another study in India reported that $\sim$ $82.1 \%$ of the PROM cases occurred at term, while $17.6 \%$ occurred before term. ${ }^{12}$ Okeke et al $(2014)^{26}$ reported an incidence of $3.3 \%$ in preterm pregnancies.

Budijaya et al (2017) $)^{4}$ also found that the highest incidence of PROM (41.05\%) occurred in primigravida. A similar result was also reported by Noor et al $(2007)^{27}$ and by Gahwagi et al (2015), ${ }^{28}$ who found that the incidence of PROM was also highest in primigravida. ${ }^{27}$ Premature rupture

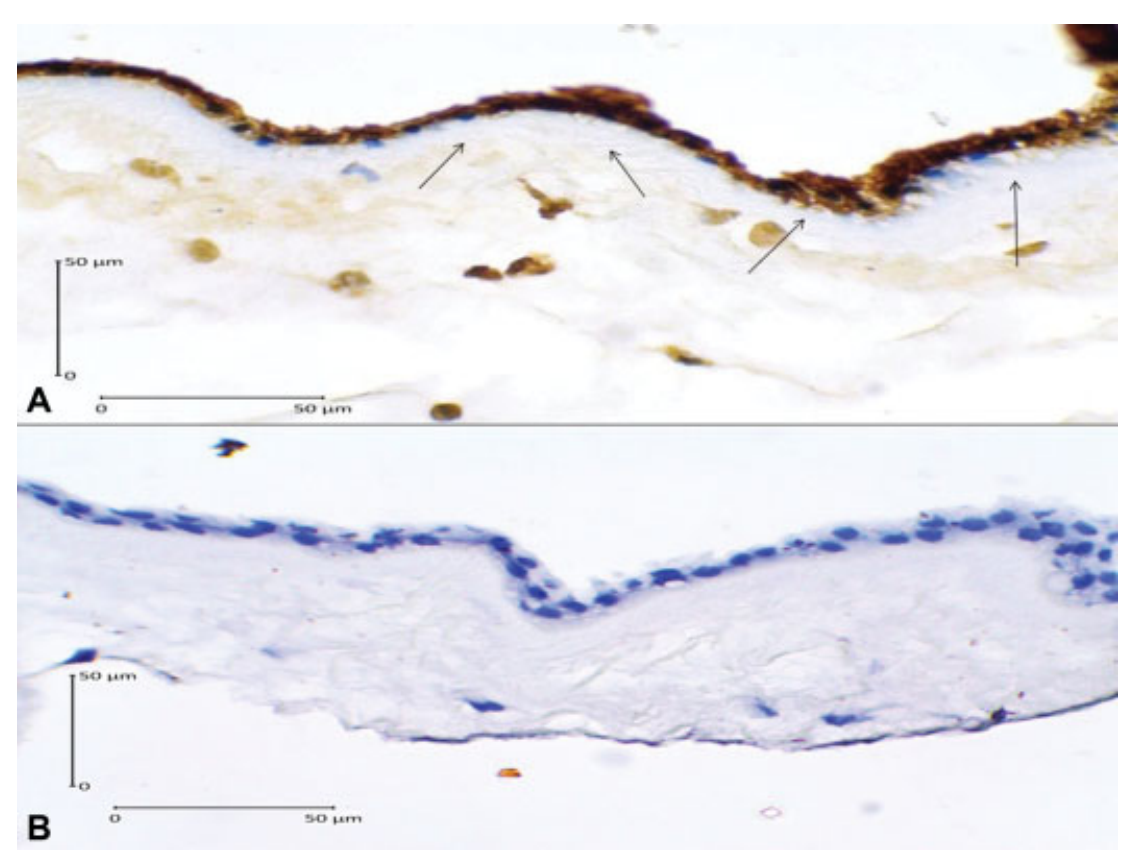

Fig. 1 Caspase-3 expression in the amniotic epithelial cells (400x magnification). (A) Positive expression shown by dark brown cytoplasm staining with blue nucleus (arrows); (B) Negative expression shown by clear cytoplasm with bright blue nucleus. 


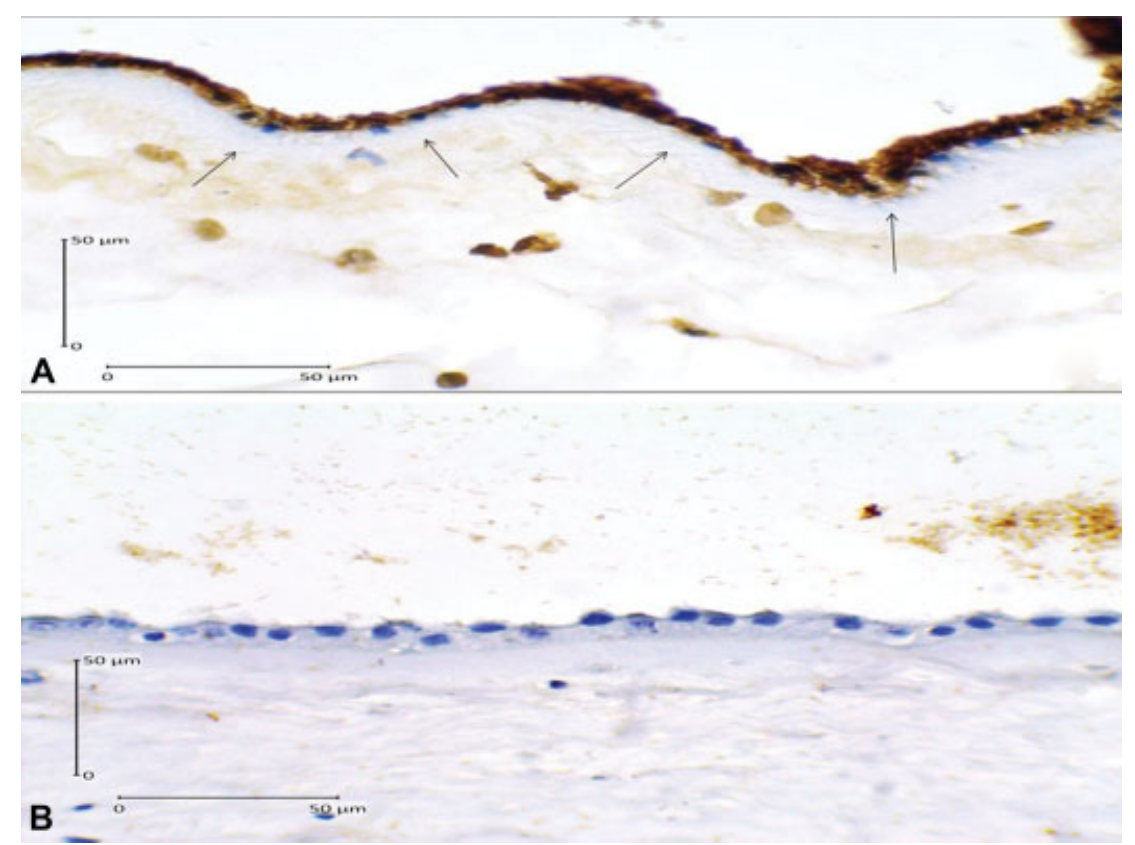

Fig. 2 Apoptosis inducing factor expression in the amniotic epithelial cells (400x magnification). (A) Positive expression shown by dark brown cytoplasm staining with blue nucleus (arrows); (B) Negative expression shown by clear cytoplasm with bright blue nucleus.

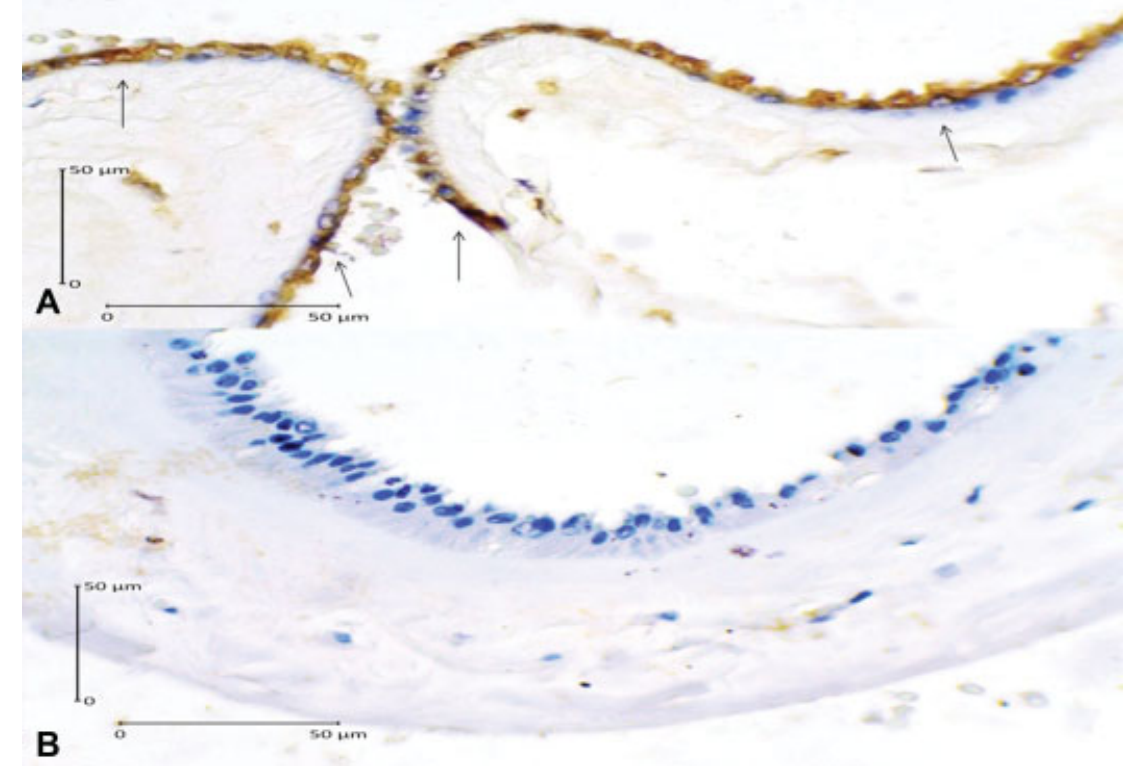

Fig. 3 B-cell lymphoma-2 expression in the amniotic epithelial cells (400x magnification). (A) Positive expression shown by dark brown cytoplasm staining with blue nucleus (arrows); (B) Negative expression shown by clear cytoplasm with bright blue nucleus.

of the membrane was found to be closely related to weight at the time of pregnancy and to a low BMI before pregnancy. ${ }^{29}$

Harirah et al (2012), ${ }^{14}$ in their study about the role of apoptosis in amniotic membranes of patients with term labor, found that the apoptotic index was increased in the chorionic trophoblast at the site of spontaneous ruptures, which was three times higher than in those patients who underwent cesarean section (CS) (artificial rupture). After vaginal delivery, the examination of the choriodecidual layer showed a higher expression of active caspase-3 pro-apopto- tic protein and a lower expression of Bcl-2 anti-apoptotic protein, when compared with the $\mathrm{CS}$ group. The $\mathrm{Bcl}-2$ protein family is the key regulator of apoptosis, comprising the antiand pro-apoptotic proteins. ${ }^{14}$

In a study by Xu et al (2005), ${ }^{13}$ it was found that the CASP-3 gene expression was increased in the amniotic membrane of PROM patients, which indicated an increase in apoptotic cells in the membranes. The increase of apoptotic cells promotes the degradation of the extracellular matrix, leading to decreased membrane elasticity and strength, ultimately causing PROM. 
Caspase expression and activation play a very important role in apoptosis. They found that caspase-3 expression was higher in patients who had vaginal delivery compared with CS. The immunohistochemical examination revealed that caspase-3 was increasingly expressed in amniotic epithelial cells and in chorionic cytotrophoblast cells, but only slightly expressed in mesenchymal and in reticular cells of the matrix. This finding shows that apoptosis may occur both in the amnion and in the chorion, and plays an important role in the regulation of the fetal membrane. ${ }^{13}$ The role of caspase- 3 on preterm PROM was also studied by Saglam et al (2013). ${ }^{15}$ Using a case-control design, they compared the immunopositivity of active caspase-3 in preterm PROM and in preterm delivery with intact membranes (case group) with term pregnancy with normal delivery (control group). It was concluded that the active caspase-3 immunopositivity of the preterm PROM group was significantly higher than that of the control group $(p<0.05) .{ }^{15}$ A similar study by Negara et al $(2017)^{30}$ found that positive caspase-3 expression increased 7.3 times the risk of PROM (OR = 7.31; CI 95\% = 2.64 to 20.22; $p=0.001$ ).

Caspase-3, which is a key factor in the apoptosis execution, is an active form of procaspase- 3 and is considered as the most important executor caspase. It is activated by an initiator caspase (caspase-8, caspase-9, caspase-10), which in turn activates caspase-activated DNase (CAD) endonuclease. In proliferating cells, CAD forms a complex with its inhibitor, known as inhibitor of caspase-activated DNase (ICAD). Contrarily, in cells undergoing apoptosis, the activated caspase- 3 cleaves ICAD, thus releasing CAD. Caspase-activated-DNase disturbs the chromosomal DNAs inside the nuclei of the cells, causing chromatin condensation. It also triggers the cytoskeletal reorganization and further disintegrates cells to form apoptotic bodies. This process results in phagocytosis. ${ }^{20}$ In our study, caspase-3 expression was significantly higher in the case group compared with the control group $(\mathrm{OR}=17.64 ; 95 \% \mathrm{CI}=4.44-$ $70.07 ; p=0.001$ ). This finding suggested that apoptosis via the caspase-dependent pathway was involved in the regulation of the amniotic membrane, and the increased expression of caspase-3 increased the risk of PROM in term pregnancies.

Apoptosis may also occur in a caspase-independent fashion. In this setting, apoptosis is mediated by mitochondrial proapotosis proteins, that is, AIF and endoG. ${ }^{20}$ When a cell receives apoptotic stimulation, AIF and endoG transcend from the mitochondria to the nucleus and stimulate DNA nuclear fragmentation. ${ }^{20,31,32}$ Apoptosis inducing factor is the first protein to mediate caspase-independent cell death. Formerly, AIF was considered as a soluble protein in the intermembranous space of mitochondria, that could be transferred into the nucleus to participate in large-scale DNA fragmentation and chromatin condensation. However, further studies found that AIF is the amino-terminal (N-terminal) and is anchored to the inner mitochondrial membrane. Therefore, AIF must be released from the mitochondrial membrane before it reaches the cytoplasm. It is believed that upon entry into the nucleus, AIF recruits or activates endonucleases to facilitate DNA fragmentation and chromatin condensation. ${ }^{20}$

Apoptosis inducing factor has the capacity to activate independent peripheral caspases and to induce chromatin condensation and DNA fragmentation when specific extracellular signals trigger mitochondrial permeability transition pore (MPTP) opening. This event allows the release of AIF and other apoptogenic effectors, such as apoptosis protease activating factor 1 (APAF-1) and cytochrome C, both of which can activate caspase cascade. Cytosolic AIF triggers the release of more AIF from the mitochondria, forming a selfreinforcing circle that accelerates apoptosis. The proteins of the Bcl-2 anti-apoptosis family serve as protective agents of the mitochondrial membrane to prevent the release of cytochrome $C$ and AIF. In the mitochondrial membrane, the $\mathrm{Bcl}-2$ protein is also involved in regulating the redistribution of AIF in the mitochondrial nucleus. ${ }^{33-35}$

In the present study, we have found that high AIF expression increased 9.45 times the risk of PROM $(\mathrm{OR}=9.45 ; 95 \% \mathrm{CI}$ $=2.62-34.07 ; p=0.001$ ). This finding suggested that caspase-independent apoptosis was also involved in the mechanism of PROM. Recent studies have shown that some types of cell death may take place in the absence of caspase activation. In some models of cell death, certain caspase inhibitors cannot prevent apoptosis stimulated by pro-apoptotic signals, and caspase activation only is not sufficient to initiate apoptosis. In addition, Bax or Bak expression induces cell death without involving caspase, which indicates that factors other than caspase may also mediate apoptosis. Some of these factors are of mitochondrial origin (such as AIF) and cause mitochondrial swelling, chromatin condensation, and cytochrome $\mathrm{C}$ release in the absence of caspase activation. ${ }^{25}$

Cytochrome $\mathrm{C}$ release from mitochondria can be triggered by various stress signals originating from the inside of the cell or following caspase activation that is stimulated by surface receptor ligands. The integrity of the outer membrane and the release of cytochrome $\mathrm{C}$ from the mitochondria are governed by proteins of the Bcl-2 family, comprising anti-apoptotic factors such as Bcl-2 and B-cell lymphoma-extra large (Bcl$\mathrm{XL}$ ), and also pro-apoptotic proteins such as Bax and Bak. These proteins may undergo heterodimerization with each other and interact with the mitochondria, where they play a key role in determining whether the cell will live or die. Thus, Bcl-2 proteins prevent apoptosis by preventing the release of proteins from mitochondrial membranes (i.e. cytochrome $\mathrm{C}$ and AIF), while Bax stimulates the release of cytochrome $C$ from mitochondria, resulting in apoptosis. ${ }^{25}$

Obligate intracellular bacterial infection is the most common condition in which the caspase-independent pathway takes action. This is made possible by the direct destructive ability of the bacteria on the mitochondrial membrane, resulting in DNA fragmentation and nuclear chromatin division to produce oligonucleosomal DNA fragments. Biochemical and genetic studies show that AIF and endoG are involved in DNA fragmentation through the mitochondrial pathway because it is located within the mitochondria. ${ }^{36,37}$

In the present study, it was found that low Bcl-2 expression increased 10.39 times the risk of PROM (OR $=10.39$; $95 \% \mathrm{CI}=2.73-39.56 ; p=0.001)$. A study by Harirah et al $(2012)^{14}$ found that patients with spontaneous rupture of membrane demonstrate a higher expression of active caspase-3 and a lower expression of Bcl-2. In early pregnancy, 
apoptosis in the amniotic epithelium is independent of Bcl-2 activity, but at the end of pregnancy, it may have an important role in membrane weakness and rupture. ${ }^{38}$

A research by Fortunato et al $(2001)^{39}$ on apoptosis and matrix metalloproteinase-2 (MMP-2) activation in PROM found that the increased expression and activity of MMP-2 is associated with PROM. A pro-apoptotic protein, such as p53, is produced in response to the fragmentation of DNA, binding to MMP-2 gene promoters and leading to increased gene expression. This protein causes apoptosis by inducing the expression of the $B A X$ pro-apoptosis gene and inhibiting BCL2 anti-apoptosis gene expression. In PROM, pro-apoptotic genes expression ( $B A X$ and $p 53$ ) are increased, whereas the anti-apoptotic $B C L 2$ gene expression is decreased. ${ }^{10}$ These findings are similar with our study, which suggests that $\mathrm{Bcl}-2$ is an anti-apoptosis protein that regulates the apoptotic process in the fetal membrane, and its decrease is a risk factor for PROM.

The Bcl-2 family is a key regulator of apoptosis and is an essential component of the intrinsic pathway, regulating the permeability of the outer mitochondrial membrane and the release of pro-apoptotic factors, such as cytochrome C. In addition, members of the Bcl-2 family also connect both to the extrinsic and to the intrinsic pathways. ${ }^{20}$ The intrinsic pathway is centered in the mitochondria, with the Bcl-2 family as its main regulator. Its main action takes place in the outer membrane of the mitochondria, in which the apoptogenic factors are stored. Upon release, these apoptogenic proteins will activate caspase, as the executor of apoptosis. ${ }^{20,40,41}$

\section{Conclusion}

Our findings suggest that apoptosis was involved in the mechanism of PROM. In patients at term pregnancy, caspase-dependent and -independent pathways of apoptosis were involved, evidenced by the high caspase- 3 and AIF expressions, as well as by the low Bcl-2 expression. From the present study, we can conclude that a high expression of caspase- 3 and AIF, and a decreased expression of Bcl-2, were risk factors for term PROM.

\section{Contributions}

Substantial contributions to the conception and design, data collection or analysis, and interpretation of data: Ketut Surya Negara, Nyoman Mantik Astawa, I Gusti Nyoman Kamasan Arijana, Ketut Tunas. Writing of the article or critical review of the intellectual content: Ketut Surya Negara, Tjokorda Gede Astawa Pemayun. Final approval of the version to be published: Ketut Suwiyoga, Anak Agung Raka Sudewi.

\section{Conflicts of Interest}

The authors have no conflicts of interest to declare.

\section{References}

1 Adeniji AO, Atanda OOA. Interventions and neonatal outcomes in patients with premature rupture of fetal membranes at and beyond
34 weeks gestational age at a tertiary health facility in Nigeria. $\mathrm{Br} \mathrm{J}$ Med Med Res 2013;3:1388-1397 Doi: 10.9734/BJMMR/2013/3428

2 Endale T, Fentahun N, Gemada D, Hussen MA. Maternal and fetal outcomes in term premature rupture of membrane. World J Emerg Med 2016;7(02):147-152 Doi: 10.5847/wjem.j.1920-86 42.2016.02.011

3 Yu H, Wang X, Gao H, You Y, Xing A. Perinatal outcomes of pregnancies complicated by preterm premature rupture of the membranes before 34 weeks of gestation in a tertiary center in China: A retrospective review. Biosci Trends 2015;9(01):35-41 Doi: 10.5582/bst.2014.01058

4 Budijaya M, Surya Negara K. Labor profile with Premature Rupture of Membranes (PROM) in Sanglah Hospital, Denpasar, Bali, Period January 1-31 December, 2015. Int J Sci Res 2017;6:348-353

5 Mercer BM. Preterm premature rupture of the membranes. Obstet Gynecol 2003;101(01):178-193

6 Dars S, Malik S, Samreen I, Kazi RA. Maternal morbidity and perinatal outcome in preterm premature rupture of membranes before 37 weeks gestation. Pak J Med Sci 2014;30(03):626-629 Doi: 10.12669/pjms.303.4853

7 Patil S, Patil V. Maternal and foetal outcome in premature rupture of membranes. IOSR J Dent Med Sci 2014;13:56-83 Doi: 10.9790/ 0853-131275683

8 Linehan LA, Walsh J, Morris A, et al. Neonatal and maternal outcomes following midtrimester preterm premature rupture of the membranes: a retrospective cohort study. BMC Pregnancy Childbirth 2016;16:25 Doi: 10.1186/s12884-016-0813-3

9 Rodrigo MRR, Kannamani A. Perinatal and maternal outcome in premature rupture of membranes. J Evol Med Dent Sci 2016; 5:3245-3247

10 Menon R, Fortunato SJ. The role of matrix degrading enzymes and apoptosis in rupture of membranes. J Soc Gynecol Investig 2004; 11(07):427-437 Doi: 10.1016/j.jsgi.2004.04.001

11 Benirschke K, Burton GJ, Baergen RN. Anatomy and pathology of the placental membranes. In: Benirschke K, Burton GJ, Baergen RN. Pathology of the human placenta. Berlin: Springer; 2012:249-307

12 Vishwakarma K, Patel SK, Yadav K, Pandey A. Impact of premature rupture of membranes on maternal \& neonatal health in Central India. J Evid Based Med Health Care 2015;2:8505-8508 Doi: $10.18410 / \mathrm{jebmh} / 2015 / 1165$

$13 \mathrm{Xu} \mathrm{J}$, Wang HL. Role of Caspase and MMPs in amniochorionic during PROM. J Reprod Contracept 2005;16:219-224

14 Harirah HM, Borahay MA, Zaman W, Ahmed MS, Hankins GD. Increased apoptosis in chorionic trophoblasts of human fetal membranes with labor at term. Int J Clin Med 2012;3(02): 136-142 Doi: 10.4236/ijcm.2012.32027

15 Saglam A, Ozgur C, Derwig I, Unlu BS, Gode F, Mungan T. The role of apoptosis in preterm premature rupture of the human fetal membranes. Arch Gynecol Obstet 2013;288(03):501-505 Doi: 10.1007/s00404-013-2774-3

16 Kataoka S, Furuta I, Yamada H, et al. Increased apoptosis of human fetal membranes in rupture of the membranes and chorioamnionitis. Placenta 2002;23(2-3):224-231 Doi: 10.1053/plac.2001.0776

17 El Khwad M, Stetzer B, Moore RM, et al. Term human fetal membranes have a weak zone overlying the lower uterine pole and cervix before onset of labor. Biol Reprod 2005;72(03):720-726 Doi: 10.1095/biolreprod.104.033647

18 Rangaswamy N, Mercer BM, Kumar D, et al. Weakening and rupture of human fetal membranes-biochemistry and biomechanics. In: Morrison J, ed. Preterm Birth: Mother and Child. London: InTech; 2012:151-182

19 van Loo G, Schotte P, van Gurp M, et al. Endonuclease G: a mitochondrial protein released in apoptosis and involved in caspase-independent DNA degradation. Cell Death Differ 2001; 8(12):1136-1142 Doi: 10.1038/sj.cdd.4400944

20 Elmore S. Apoptosis: a review of programmed cell death. Toxicol Pathol 2007;35(04):495-516 Doi: 10.1080/01926230701320337 
21 Ashkenazi A, Salvesen G. Regulated cell death: signaling and mechanisms. Annu Rev Cell Dev Biol 2014;30:337-356 Doi: 10.1146/annurev-cellbio-100913-013226

22 Estaquier J, Vallette F, Vayssiere JL, Mignotte B. The mitochondrial pathways of apoptosis. Adv Exp Med Biol 2012;942:157-183 Doi: 10.1007/978-94-007-2869-1_7

23 Galluzzi L, Kepp O, Trojel-Hansen C, Kroemer G. Mitochondrial control of cellular life, stress, and death. Circ Res 2012;111(09): 1198-1207 Doi: 10.1161/CIRCRESAHA.112.268946

24 Hongmei Z. Extrinsic and intrinsic apoptosis signal pathway review. In: Ntuli T, ed. Apoptosis and Medicine. London: InTech; 2012:3-22

25 Perfettini JL, Hospital V, Stahl L, Jungas T, Verbeke P, Ojcius DM. Cell death and inflammation during infection with the obligate intracellular pathogen, Chlamydia. Biochimie 2003;85(08): 763-769 Doi: 10.1016/j.biochi.2003.08.006

26 Okeke TC, Enwereji JO, Okoro OS, Adiri CO, Ezugwu EC, Agu PU. The incidence and management outcome of Preterm Premature Rupture of Membranes (PPROM) in a tertiary hospital in Nigeria. Am J Clin Med Res 2014;2:14-17 Doi: 10.12691/ajcmr-2-1-4

27 Noor S, Nazar AF, Bashir R, Sultana R. Prevalance of PPROM and its outcome. J Ayub Med Coll Abbottabad 2007;19(04):14-17

28 Gahwagi MMM, Busarira MO, Atia M. Premature rupture of membranes characteristics, determinants, and outcomes of in Benghazi, Libya. Open J Obstet Gynecol 2015;5:494-504 Doi: 10.4236/ojog.2015.59072

29 Thombre MK. A review of the etiology epidemiology prediction and interventions of preterm premature rupture of membranes [thesis]. East Lansing, MI: Michigan State University; 2014

30 Negara KS, Suwiyoga K, Arijana K, Tunas K. Role of Caspase-3 as risk factors of premature rupture of membranes. Biomed Pharmacol J 2017;10:2091-2098 Doi: 10.13005/bpj/1332

31 Candé C, Cohen I, Daugas E, et al. Apoptosis-inducing factor (AIF): a novel caspase-independent death effector released from mitochondria. Biochimie 2002;84(2-3):215-222 Doi: 10.1016/S03009084(02)01374-3
32 Arnoult D, Gaume B, Karbowski M, Sharpe JC, Cecconi F, Youle RJ. Mitochondrial release of AIF and EndoG requires caspase activation downstream of Bax/Bak-mediated permeabilization. EMBO J 2003;22(17):4385-4399 Doi: 10.1093/emboj/cdg423

33 Rastogi RP. Richa, Sinha RP. Apoptosis: molecular mechanisms and pathogenicity. EXCLI J 2012;8:155-181

34 Akematsu T, Endoh H. Role of apoptosis-inducing factor (AIF) in programmed nuclear death during conjugation in Tetrahymena thermophila. BMC Cell Biol 2010;11:13 Doi: 10.1186/1471-2121$11-13$

35 Sevrioukova IF. Apoptosis-inducing factor: structure, function, and redox regulation. Antioxid Redox Signal 2011;14(12):2545-2579 Doi: 10.1089/ars.2010.3445

36 Prabantoro BTR, Prabowo P, Mertaniasih NM, Rantam FA. The role of endonuclease-G for amniotic cell apoptosis biomarker determination in pregnancies with premature rupture of the membrane. Biosains 2011;13:27-37

37 Gao LY, Kwaik YA. The modulation of host cell apoptosis by intracellular bacterial pathogens. Trends Microbiol 2000;8(07): 306-313 Doi: 10.1016/S0966-842X(00)01784-4

38 Kumagai K, Otsuki Y, Ito Y, Shibata MA, Abe H, Ueki M. Apoptosis in the normal human amnion at term, independent of Bcl-2 regulation and onset of labour. Mol Hum Reprod 2001;7(07): 681-689

39 Fortunato SJ, Menon R, Lombardi SJ. Support for an infectioninduced apoptotic pathway in human fetal membranes. Am J Obstet Gynecol 2001;184(07):1392-1397, discussion 1397-1398 Doi: 10.1067/mob.2001.115434

40 Shiozaki EN, Shi Y. Caspases, IAPs and Smac/DIABLO: mechanisms from structural biology. Trends Biochem Sci 2004;29(09): 486-494 Doi: 10.1016/j.tibs.2004.07.003

41 Negara KS, Suwiyoga K, Arijana K, Tunas K. Role of Apoptosis Inducing Factor (AIF) as risk factors of premature rupture of membranes. Biomed Pharmacol J 2018;11:719-724 Doi: 10.13005/bpj/ 1425 